\title{
Examining Principals' Perceptions of Their Influence on Science Achievement
}

\author{
Pat J. Casey (Corresponding Author) \\ Department of Educational Leadership and Policy Studies, University of Texas at Arlington \\ Box 19575, 701 Planetarium Place, Arlington, TX, USA 76019-0575 \\ Tel: 1-512-775-4104 E-mail: pjcasey@uta.edu
}

Karen Dunlap

Department of Teacher Education, Texas Woman’s University

P.O. Box 425769, Denton, TX, USA 76204-5769

Tel: 1-940-898-2764Ｅ-mail: kdunlap@twu.edu

Teresa M. Starrett

Department of Teacher Education, Texas Woman’s University

P.O. Box 425769, Denton, TX, USA 76204-5769

Tel: 1-940-898-2764Ｅ-mail: tstarrett@twu.edu

Received: April 2, 2012 Accepted: April 16, 2012 Published: May 1, 2012

doi:10.5296/jse.v2i2.1586 URL: http://dx.doi.org/10.5296/jse.v2i2.1586

\begin{abstract}
This study surveyed a random sample of elementary principals in Texas. The 85 principals completed an anonymous online survey with both closed and open ended questions. Findings are presented as descriptive statistics of rating scale items and patterns and themes that emerged from the responses to the open ended questions. Participants described leadership behaviors they perceived to influence students' performance on the $5^{\text {th }}$ grade state science exam. Principals described, for example, their involvement in building the capacity of staff to plan and deliver effective science instruction and how they organized (e.g. departmentalized vs. self-contained) science classes for increased student learning. Further, the principals
\end{abstract}




\section{Macrothink

indicated their concerns about high stakes testing as they repeatedly referred to their involvement in benchmark testing and providing remedial instruction for students.

Keywords: Educational leadership, Student achievement, Science education, Principal 


\section{Principals' Perceptions of Their Influence on Science Achievement}

\subsection{Context of the study}

In this study we explored how principals perceived their influence on student science achievement on elementary campuses in Texas. In Texas, student achievement is a key component in the evaluation of educators and campuses. Expectations for student performance are established by state and federal guidelines and campuses may be sanctioned for failing to meet expectations. Accordingly, in Texas as in most states, school principals are expected to ensure that students perform at an acceptable level on the state science test.

At the time of this study, science was first tested on the Texas Assessment of Knowledge and Skills (TAKS) in the fifth grade. Campuses were rated as academically unacceptable, academically acceptable, recognized, or exemplary based on the percentage of students who met minimum standards on the test (Texas Education Agency, 2009).

The 85 elementary school principals who participated in the online survey described leadership behaviors that influenced student success on their campuses. As such, this work contributes to an ongoing dialogue about the connection between school leadership and student achievement. Specifically, we explored how principals perceived their influence related to science achievement in elementary schools in Texas.

\subsection{Effects of Leadership}

Various other factors contribute to student performance and mediate the effects that can be attributed to campus leadership. For example, student achievement is more directly influenced by the classroom teacher. In their seminal work, Hallinger and Heck (1998) found a small indirect effect on student performance could be attributed to campus leadership. Later, Leithwood and Jantzi (1999) reported nearly 20\% of the effect a school has on student performance can be traced back to the influence of principal leadership. Other authors have thoroughly reviewed the literature confirming the effect of principal leadership on student achievement and exploring the various factors that mediate this effect (Hallinger \& Heck, 1998; Robinson, Lloyd \& Rowe, 2008; Supovitz, Sirinides, \& May, 2010). Further, some researchers have attempted to illuminate how principals and teachers make a difference. For example, Witziers, Bosker and Kruger (2003) and Waters, Marzano, and McNulty (2003) found some effect in studies of specific leadership behaviors/activities.

\subsection{Accountability Measures}

Campus and student performance are increasingly defined by accountability system requirements and tests that are not developed or controlled by teachers or principals as is the case in the Texas elementary schools that provide the settings for this study. The tests and measures used to rate campuses have provoked considerable debate highlighting pros and cons of high stakes testing and reporting practices that have consequences for students and educators. Traditionally, the elementary principal, as the science leader, was charged with securing resources, providing in-service science training, monitoring science data and troubleshooting science problems (Mechling \& Oliver, 1982). Decades later, expectations for 
principals appear to be much more complex with an escalating focus on instructional improvement (Vanderhaar, Munoz, \& Rodosky, 2007).

Holding principals accountable for student performance is based on the notion that principals influence conditions that make good teaching and learning possible (Ross \& Gray, 2006). Since Edmonds (1979), scholars and practitioners have increasingly looked at the influence of school leadership on student success; and recent measures to hold schools and educators accountable have sharpened the focus on student performance.

According to Zhao (2009), good scores in math, reading and science are considered by many to be synonymous with good schools. This study builds on the notion that principals have a measureable effect on student achievement, and that certain behaviors and activities can influence achievement. Thus, we focus on three notions characterized as components of instructional leadership that seem to hold promise for influencing student achievement: goal setting, building capacity, and structure/organization.

\subsection{Conceptual framework}

Drawing from the body of literature describing the influence of different types and styles of leadership, this study focused on the link between instructional leadership and increased student achievement (Dumay, 2009). Specifically, we used three main ideas from the broad lens of instructional leadership focusing on how principals impact instruction - goal setting, building capacity, and structure/organization. We examined how the principals in this study employed these three dimensions of leadership (Leithwood, Seashore Louis, Anderson \& Wahlstrom, 2004; Robinson, Lloyd \& Rowe, 2008) to increase student performance.

\subsection{Factors in Instructional Leadership}

Leadership practices and principals' behaviors that increase student performance have been explored for decades. Many authors have grouped leadership practices and investigated how those practices were connected to or, moreover, influenced the improvement of student achievement. For example, Leithwood, Seashore Louis, Anderson and Wahlstrom (2004) investigated leadership practices that contribute to student achievement. Later, Robinson et al. (2008) analyzed findings from studies linking leadership to student outcomes. They found evidence supporting the links from "dimensions" (p. 658) of leadership or "sets of leadership practices” (p.635) to student performance. Accordingly, this study was framed using three interwoven notions of leadership that impact student achievement and seem to be well supported in the literature: (a) goal setting, (b) building capacity, and (c) providing organizational structure and resources that support instruction.

\subsection{Goal Setting}

Bryk (2010) identified supports known to be critical to the success of elementary schools. For example, "a coherent instructional guidance system” (p. 24) was found to be essential. The author suggested that student learning improves, and schools consequently improve, when the school environment provided cohesive and focused support for academic goals. Further, 
student achievement improved in schools wherein resources and energy were directed at the fulfillment of learning goals.

Principals are typically charged with developing and fostering campus goals. Campus principals are often referred to as the people responsible for ensuring that the campus realizes a worthy vision that often includes some version of success for all students and support by the community/stakeholders. Previous authors have pointed out that principals influence student performance by "stimulating teachers' awareness of the need for improving pupil achievements” (van de Grift \& Houtveen, 1999, p.387).

Leithwood, Seashore Louis, Anderson and Wahlstrom (2004) proposed that schools, like other organizations, need leaders to set goals or direction and then help others to follow. Leithwood et al. reported that "those leadership practices included in Setting Directions, account for the largest proportion of the leader's impact” (p.8). They included in their description of setting directions, for example, identification and articulation of the school vision and creation of high expectations for student performance. Later, Leithwood, Patten, and Jantzi (2010) also evidenced the notion that effective principals establish, articulate, and monitor expectations/goals for student performance.

Clear and compelling goals for high student achievement set direction that keeps the campus on course (Robinson et al., 2008). Hallinger (2011) argued that "The ability to articulate a learning focused vision that is shared by others and to set clear goals creates a base for all other leadership strategies and actions” (p.137). Specifically, the extent to which a school is focused on student achievement as a core purpose has been linked to student achievement and has a high sense of self-efficacy held individually and collectively by teachers (McGuigan \& Hoy 2006). As such, principals who communicate a strong and focused message about student achievement and foster teachers' capacity to achieve these goals contribute to better outcomes for students.

\subsection{Building Capacity}

One of the most important roles played by the campus principal is that of building individual and collective capacity of the staff to achieve established goals. Accordingly, to improve instruction in science, principals become involved in the teachers' professional learning (Wenglinsky \& Silverstein, 2007). Hallinger and Murphy (1987) found that effective principals encouraged professional development and monitored instructional practices. However, they further hypothesized that principals' limited knowledge of curricula often constrained their ability to lead in these areas.

Bryk (2010) argued that professional capacity is critical to school improvement. Because schools depend heavily on the effective deployment of human resources, hiring, keeping and building capacity of personnel may have the greatest impact on student achievement. Hallinger (2011) concurred; finding that leadership for improving schools/achievement what he calls leadership for learning - seeks to build the capacity of the school and the individuals in it. 
Elementary principals have been charged with providing science training that meets the needs of the teachers on their campuses (Mechling \& Oliver, 1982), i.e. professional development that is specific to the context and individuals involved. Campus leaders have a wide range of models available to them that can be used to provide training opportunities that enhance teacher performance.

Strategic leadership grounded in peer influence and collaboration has also been linked to improved student performance, albeit indirectly (Supovitz, Sirinides, \& May, 2010). The National Science Teachers Association [NSTA] in a position paper called Leadership in Science Education calls leaders to engage with teachers in promoting professional development that improves science instruction and curriculum and assessment (NSTA, n.d.). Interestingly, a principal's leadership in providing and engaging in focused professional development for science teachers depends somewhat on the principal's knowledge and understanding of the topic. Moreover, Lewthwaite (2004) found that principals were key to the improvement of curriculum delivery as well as the cultivation of the school's focus on the science; including teachers' content knowledge, pedagogical ability and attitudes toward science. This ability to enhance a teacher's capacity to improve student learning depended upon the principal's understanding of the 'technical core' of education - the what and how of teaching - content and pedagogy (Leithwood \& Reihl, 2003).

Considerable attention has been given to professional learning communities and teacher collaboration in schools. Further, authors suggest that when principals initiate and sustain structures that support ongoing teacher collaboration, teacher performance improves and; as a result, student performance improves (Leithwood, Seashore Louis, Anderson \& Wahlstrom, 2004; Witziers, Bosker \& Kruger, 2003). While some studies show powerful results, several authors caution that the evidence supporting these links may not always be generalizable (Leithwood, Seashore Louis, Anderson \& Wahlstrom, 2004).

Principals affect student achievement by influencing teachers (Vanderhaar, Munoz, \& Rodosky, 2007). Thus, it follows that leaders can improve student learning by improving teacher performance. Other authors have found instruction can be improved with subject or content focused professional development that includes an emphasis on pedagogical skills (Dumay, 2009; Firestone, Mangin, Martinez, \& Polovsky, 2005). Additionally, leadership practices that acknowledge and develop teachers' leadership abilities can lead to improved student achievement (Crum, Sherman, \& Myran, 2009).

\subsection{Organizational Structures and Practices}

As with professional development, organizational structures that work for one principal may not work for another or may not work in another situation. While achievement is influenced by principals' active engagement in the process of instruction, the success of leaders and the strategies they choose are highly contextualized (Hallinger, 2011). Further, leadership to improve student learning relies heavily on what leaders do to develop and maintain an environment that nurtures high levels of teaching and learning (Leithwood et al., 2004). A principal's knowledge of science content/curriculum and pedagogy is key to the principal's 
ability to support high-quality science instruction (Supovitz, Sirinides, \& May, 2010; Marzano, Waters, \& McNulty, 2005; Ylimaki, 2007).

Elementary school principals are typically responsible for a variety of tasks that have the potential to impact student achievement in science. Among the tasks most strongly associated with student performance are staffing, scheduling, supervision of science instruction, and providing resources (Marzano, Waters, \& McNulty, 2005). Principals must know the skills and abilities of their teachers, protect instructional time from distractions, consistently monitor effectiveness of the science program and instruction, and equip teachers with the materials they need to be successful.

Overall, the evidence suggests that campus leadership works in concert with other variables such as teacher quality and school context in the complex picture of student achievement. The literature links leadership to student achievement in several ways. Goal setting, building capacity and organizational structures/practices are three ways supported in the literature that principals seek to improve the quality of science education and, thereby, improve student learning. Accordingly, this study seeks to describe how elementary principals described their influence in science education and, consequently, student achievement.

\section{Methods}

This study explored elementary school principals' perceptions of the principals' role in influencing science achievement. The research questions were: (a) How do campus administrators describe their influence on $5^{\text {th }}$ grade science instruction? (b) What factors do campus administrators perceive to be important in the organization of elementary science programs?

The data source was an online survey sent to elementary principals in Texas. The principals were identified using the Texas School Directory 2009-2010 (Texas Education Agency, n.d.), contacted via email, and asked to participate in the study. The first questions solicited basic demographic information about both the respondent and the campus followed by closed ended rating scale items describing the science program at the campus. Finally, open-ended questions were asked to ascertain the principals' perceptions of their role in science instruction on their campus.

Participants' responses were grouped by corresponding campuses' TAKS scores in science for the 2008-2009 school year using the Texas Academic Excellence Indicator System (Texas Education Agency [TEA], 2009) categories based on the percentage of $5^{\text {th }}$ grade students who met minimum expectations on the state mandated science test, the Texas Assessment of Knowledge and Skills (TAKS).

Respondents were asked to provide their campus rating for the 2008-2009 state accountability ranking. In 2008-2009, to earn the Exemplary rating, at least $90 \%$ of the students tested on a campus would have to meet minimum expectations on all of the tests they took (including science); to be Recognized at least $75 \%$ met minimum expectations on all the tests taken. To achieve Academically Acceptable - for other subjects scores were higher but at least $50 \%$ had to meet minimum expectations on the science test. If less than $50 \%$ passed science, the campus 
would be ranked Academically Unacceptable (Texas Education Agency, 2009, May). None of the participants reported an Academically Unacceptable ranking.

Of the 85 participants, 26 reported their campus rating as Exemplary; 45 indicated their campus rating was Recognized; 13 stated Academically Acceptable and one respondent reported the campus rating as "other." The survey responses were analyzed collectively and then compared across groups. Responses to closed ended questions were analyzed for descriptive statistics using SPSS version 15 software. These responses helped us understand how each perceived his/her specific situation.

Responses to open-ended questions were coded and analyzed qualitatively for themes, patterns and similarities in the responses using highlighting and marginal notes. This phase of the analysis focused on each participant's individual responses, specifically that which they identified as significant experiences. To identify themes in the responses to open ended questions, we took excerpts and looked for places where the data intersected (1) among all participants and (2) with the data from the closed ended items as conceptualized by Wolcott, (2009). This compilation of responses offered a glimpse into how the principals viewed their role in the student achievement on their campuses.

\section{Findings}

This study sought to better understand how principals influence science achievement on elementary campuses. Specifically, the findings were analyzed for evidence of three themes that seem to be well supported in the literature: (a) goal setting, (b) building capacity, and (c) providing organizational structure and resources that support instruction.

Findings are considered in two ways. First, data from the closed ended survey items are presented as descriptive statistics. Second, the participants' responses to the open ended questions were coded for common themes and are presented to provide some additional insights.

\section{Overall satisfaction with science instruction}

When asked to rate the science instruction on their campuses, principals reported high satisfaction overall. Almost half (38 participants/45\%) rated science instruction as excellent and another 36 (42\%) called it good. Interestingly, the principals' rating of science instruction was not strongly correlated to their campus ranking. Of those principals reporting an excellent level of satisfaction, 18 were from campuses which had a state rating of exemplary, 16 from recognized campuses, and 4 from academically acceptable campuses. Principals indicating a good level of satisfaction came from 8 exemplary, 24 recognized, and 4 academically acceptable campuses, respectively. Of the remaining $11(13 \%)$ participants who described science instruction as fair or poor, 5 indicated they were from recognized schools and 6 from academically acceptable campuses.

Principals of recognized schools perceived certain aspects of school leadership to be more important than principals of either exemplary or acceptable campuses. The principals from recognized campuses reported five topics as extremely important in improvement of science 
performance: collaboration (57.8\%), increased time for science instruction (44.4\%), access to science facilities and laboratory equipment (53.3\%), hiring teachers with strong science background (57.8\%) and targeted professional development (37.8\%). These data may suggest that reporting principals from the recognized campuses might be most aggressively pursuing the exemplary status.

\subsection{Goal setting}

When asked "How do you, as a campus administrator, influence science instruction on your campus?" none of the respondents suggested vision or goal setting beyond the notion of "strong focus on science improvement" suggesting a focus on test scores. On another note, some of the principals said they had "high expectations" for themselves, the teachers, and/or the students. Two others recognized the power of student learning beyond what was tested on the state assessment.

The pressures of high stakes testing may sometimes blur the lines between learning and performance such that students' scores on the $5^{\text {th }}$ grade science test may be considered good evidence that students learned the science content. Concurrently, $20 \%$ of the principals reported tracking students' test scores and providing supplemental instruction or tutoring during school, after school, and/or on Saturdays.

However, only two leaders reported that they valued or supported innovative /creative instructional strategies on the part of the teachers. However, at least one of the principals from an exemplary school articulated a goal beyond the TAKS assessment. The principal of a recognized school, said, "We are very good at TAKS. I think we have moved too far into the TAKS track. My goal is to move toward students that think scientifically not just memorize science stuff.”

\subsection{Staffing and building capacity}

Teachers were the principals' main focus. The bottom line for many of the respondents was that their most effective means of influencing science achievement was to, as one said, "hire only highly qualified teachers" and then to "provide encouragement and support." The respondents repeatedly referred to the importance of finding and hiring good teachers and putting the right people in the right place or, as one said, "assigning personnel where they are needed most." One participant put it this way, "It's more about the instructor/teacher, than anything else." Another said, "I have an awesome science teacher and that is what makes the difference." And, yet another said, "Hire teachers that have the philosophy and work ethic to make things happen for kids. Last year we tested 420 fifth graders, 97\% mastered, and 80\% were commended. It is a lot of work and you have to have teacher[sic] that believe every child can do it.”

Many respondents referred to the practice of regularly monitoring science instruction, and dialogue/talking with teachers about science instruction. Principals added that they influenced instruction by providing praise, support and encouragement to teachers. The support for the teachers included a wide range of capacity building or professional development activities. Many of the respondents reported sending staff to appropriate science workshops, training, 
conferences; conducting book studies; guiding or participating in a campus based professional learning community about science; and/or providing opportunities for collaboration about science instruction and curriculum. They arranged for teachers to observe exemplary campuses and other teachers and allocated funds for additional planning and collaboration.

Included in the responses about staffing, several of the principals referred to either having access to or wanting to have access to district or campus level science coordinators, facilitators or specialists. Generally, these were considered a resource for classroom teachers and campuses, as were part time science tutors who provided supplemental instruction and science paraprofessionals who assisted with science labs or lab activities.

Concerns about high-stakes testing were evidenced in the responses that focused on staffing and building capacity of staff. One principal summed this concern saying, "Teachers need to understand what is to be taught and how it will be tested." S/he continued saying that there are "some unique ways [on the test] of illustrating the food chain, for example."

\subsection{Involvement in curriculum and instruction}

When asked how they influenced science instruction, the participants described their involvement with curriculum, assessment and instruction in a variety of ways. The reference to the "tested curriculum" as one participant said was strong. Seventeen of the participants (20\%) specifically mentioned their involvement with interim assessments or benchmark tests that were used to monitor students' progress toward master of learning goals defined by the state's TAKS assessment. The participants reported, for example, that they either met with teachers regarding the design and implementation of benchmark tests or personally created assessments, planned, scheduled, monitored, implemented, disaggregated data, and/or organized tutoring/remediation for students who did not master objectives. It is evident from the study data that principal participants felt they took an active instructional leadership role by supporting teachers in their development of appropriate content assessments based on “instructional practices and student needs."

Regarding curriculum, respondents reported seeking or acquiring science programs or curricula as a resource for teachers and/or mentioned providing support for teachers to integrate science with other content areas. Principals' involvement with curricula was most often reported as vertical alignment. One cited his/her influence by "using our vertical teams to evaluate our science instruction and to make sure that we are not overlapping instruction or teaching the same thing from grade to grade ..." Other principals pointed out that science is tested at fifth grade but acknowledged that the "foundations for that knowledge must be laid much earlier.” Thus, they perceived that they influenced $5^{\text {th }}$ grade scores when they attended to science instruction in Kindergarten through $4^{\text {th }}$ grade as well.

\subsection{Providing organizational structure and resources that support instruction}

Classroom instruction on elementary campuses is commonly designated as self-contained, meaning one classroom teacher shoulders the responsibility for teaching all core subject areas (mathematics, reading/language arts, science and social studies). Only 9 (11\%) of the 85 
principals who participated in this study described delivery of science instruction as provided in a self-contained classroom.

Interestingly, the principals of departmentalized campuses rated science instruction on their campuses as excellent or good almost $90 \%$ of the time and principals of self-contained campuses were much less likely to rate instruction as excellent. The table below indicates how principals responded when asked, "How would you rate your $5^{\text {th }}$ grade science instruction?”

Table 1: How would you rate your $5^{\text {th }}$ grade science instruction?

Excellent Good $\quad$ Fair Needs Improvement

Departmentalized $37(48 \%) \quad 31(41 \%) \quad 6(8 \%) \quad 2(3 \%)$

Self-Contained $\quad 1(11 \%) \quad 5(56 \%) \quad 1(11 \%) \quad 2(22 \%)$

In some instances, however, classes on elementary campuses (particularly, fifth grade ones), may be described as departmentalized; meaning a different teacher is responsible for specific core content/subject area instruction. In this situation, elementary students "travel" from one content specific teacher to another in a manner similar to that of "changing classes" at the middle school level. Finally, elementary classrooms may be a blend or partially departmentalized. In this scenario, students are primarily assigned to one teacher with subject area specialists that come to the homeroom classroom for content specific instruction. Almost all (90\%) of the study participants described how science was taught in a departmentalized or partially departmentalized manner. In each such case, fifth grade students were assigned to one teacher for science instruction and received other content instruction from other teacher(s). For this study, these variations on the organization of the science program that were identified as partially departmentalized and departmentalized, were collapsed and merged into one data set labeled departmentalized. This allowed a cleaner categorical analysis of data to occur between the self-contained and departmentalized to occur.

Interestingly, $88 \%$ of principals reporting their campus utilized departmentalized science instruction rated that instruction at their campus as either excellent or good. By comparison, $66 \%$ of the principals whose schools relied on self-contained science instruction ranked that instruction as either excellent or good. Most of the principals (86\%) reported that hiring/having a teacher with a strong science background was extremely or very beneficial in the organization of the science program and a significant factor in whether they chose to provide the science instruction as departmentalized (84\%) or self-contained (100\%). 
Of the principals who departmentalized, more than two thirds (68\%) said that their decision to do so was based on whether they had a strong teacher for one or more of the content areas. Consistent with their staffing decisions, organizing instruction by departmentalizing was a means to ensure that more students had access to the teacher they identified as a strong science teacher. In contrast, only 3(33\%) of the principals on self-contained campuses found the individual teachers an important factor in organizing for student achievement.

However, over half (56\%) of the principals on self-contained campuses relied much more heavily on the support of district level science coordinators or specialists to come to the campuses and help the teachers with science instruction. In contrast, less than an third (29\%) of the principals from departmentalized campuses found visits from or time with district science coordinators/specialists to be beneficial or important in influencing student achievement.

Additionally, the principals reported other factors as extremely or very beneficial factors in student achievement. Factors that were high and consistent with all 85 principals included increased time for science instruction (72\%); integration of science content with other subject areas (75\%); and professional development in science instruction (78\%).

Principals of recognized schools perceived certain aspects of school leadership to be more important than principals of either exemplary or acceptable campuses. The principals from recognized campuses reported five topics as extremely important in improvement of science performance: collaboration (57.8\%), increased time for science instruction (44.4\%), access to science facilities and laboratory equipment (53.3\%), hiring teachers with strong science background (57.8\%) and targeted professional development (37.8\%). We found these data most compelling as they caused us to speculate that the principals of the recognized campuses might be most aggressively pursuing the exemplary status.

\subsection{Themes from the responses to the open ended questions}

One participant summed up the data saying, "I have control of two things as an administrator: resources and choice of instructor. I make sure the instructor has all the resources she needs including time and I hired one of the best instructors that had a strong background in science for the job.” There was no escaping the respondents' "strong focus on science improvement," as one participant said. The responses to the open ended questions suggested that principals influenced student outcomes in science though (a) their work with teachers and (b) the resources they provided.

\subsection{Allocating resources}

Second only to the effect the respondents reported from their work with teachers, was the notion that they influenced science instruction on their campuses through allocation of resources-finding and providing instructional materials, time for science instruction, field trips, and science coordinators, for example. According to the principal of one exemplary campus, "I influence instruction by purchasing materials needed for labs and buying books to integrate science into the language arts.” Others referred to acquiring grants for materials, ensuring that 
teachers had materials for 'hands on' activities and using funds for science books that teachers could use for reading instruction.

\section{Discussion}

This study explored 85 elementary principals' perceptions of their influence on students' achievement in science. The research questions were: (a) How do campus administrators describe their influence on $5^{\text {th }}$ grade science instruction? and, (b) What factors do campus administrators perceive to be important in the organization of elementary science programs? The source of data was an online survey with rating scale items and open-ended questions. To examine the principals' perceptions of their own agency/effect in this matter, we used, as a guide three dimensions of leadership that are linked to increased student performance - goal setting, building capacity, and structure/organization.

Of the three dimensions of leadership considered, goal setting was the least pronounced in the principals' description of their influence. These elementary school principals described their role in increasing student performance as mostly about staffing and building the capacity of staff and about structure/organization and allocation of resources.

\subsection{Goal setting}

While a few of the 85 principals in this study described holding high expectations for themselves and others, these expectations were directed toward performance on the state test. While others authors provide a clear and compelling argument for goal setting as a foundation for other leadership actions (Bryk, 2010; Hallinger, 2011; Leithwood, Seashore Louis, Anderson \& Wahlstrom, 2004), these self-reported data do not extend much beyond the notion of "high expectations" in supporting the contribution of goal setting in the influence of student outcomes.

The high stakes nature of the science test may have narrowed or displaced the participants' goals for student success as evidenced by the one participant who explained that his/her campus was, "very good at TAKS. I think we have moved too far into the TAKS track. My goal is to move toward students that think scientifically not just memorize science stuff.”

\subsection{Building capacity}

These data suggest that the principals perceive their influence to be most strongly linked to their role in supporting instruction through supervision and hiring the best teachers. Hiring and staffing practices; supervising and providing professional development for teachers; and organizing the science program to best utilize teachers' strengths were often reported as strategies used to improve student outcomes. Research has illuminated the principal's role in building the capacity of the staff as a means to improve student performance (Hallinger, 2011; Leithwood, Seashore Louis, Anderson \& Wahlstrom, 2004; Wenglinsky \& Silverstein, 2007).

Principals in this study focused on hiring teachers they considered to be the best available. They reported frequent monitoring and the use of praise, recognition and monitoring to stimulate and sustain teachers' effectiveness. Participating principals described using a variety of activities including, for example, targeted (science focused) professional development 
sessions, collaboration and teamwork to further teachers' knowledge of science curricula and instructional techniques.

The focus on the test was evident in the principals' efforts to influence student achievement in science. Clearly, principals recognized that they influenced instruction by ensuring that the teachers were effective. The bottom line for teacher support and capacity building was that, as expressed by one principal, the teachers needed to know what was to be tested and how it would be tested.

\subsection{Structure /organization}

These data suggest that principals' influence rested largely on how they selected and supported the teachers and, furthermore, an individual teachers' strength as a science instructor was a significant factor in the principals' decision making about the organization of the sciences classes for the fifth grade students. Principals who departmentalized for science instruction were more likely to consider the science instruction on their campuses excellent.

Beyond the clear emphasis on staffing for students' success, the principals reported influencing by providing a variety of resources to ensure effective implementation of curricula and instructional practices. Further, most of the principals agreed that increasing time for science instruction and integrating science content with other subject areas were beneficial in increasing student achievement. This finding is consistent with that of Marzano, Waters, \& McNulty (2005) who found that staffing, scheduling, supervision of instruction, and providing resources are among the leadership tasks most strongly associated with student performance.

\section{Implications}

Our data suggest that Texas principals organize people according to strengths, value collaboration and professional learning with and among teachers, and apply resources (other than human resources) as best they can to facilitate the students' academic success in any case. The high-stakes science testing may have some bearing on the principals' perceived use of leadership actions. For example, while the literature reports goal setting as an important component of leadership that influences student achievement, these elementary school principals did not articulate goal setting as one of their primary leadership considerations. Their focus was clearly and consistently on their role in finding strong science teachers and supporting them as much as they could with time, professional development and material resources.

Nearly all of those who responded to our invitation were principals of exemplary (31\%) or recognized (53\%) schools; no participant reported the campus had been labeled as academically unacceptable. Principals of low performing schools may have been less likely to participate in a survey as time was viewed as a sacred commodity to be used wisely. Any principal of a low performing school in Texas was expected to remain focused on student achievement and the strategies, programs, and protocols necessary to shed that label. This is consistent with the ideas presented by other authors who illuminate the increasing complexity of the principal's role and powerful focus on testing and accountability systems that can 
produce serious consequences for principals (Vanderhaar, Munoz, \& Rodosky, 2007; Ylimaki, 2007; Stark-Price, Munoz, Winter, \& Petrosko, 2006).

\section{References}

Author. (n.d.). NSTA Position Paper: Leadership in Science Education. National Science Teachers' Association. Retrieved from http://www.nsta.org/pdfs/PositionStatement_Leadership.pdf

Bryk, A.S. (2010, April). Organizing schools for improvement: Research on Chicago school improvement indicates that improving elementary schools requires coherent, orchestrated action across five essential supports. Phi Delta Kappan, 91 (7), 23-30.

Crum, K.S., Sherman, W.H., \& Myran, S. (2009). Best practices of successful elementary school leaders. Journal of Educational Administration, 48(1), 48-63. http://dx.doi.org/10.1108/09578231011015412

Dumay, X. (2009, July 29). Origins and consequences of schools' organizational culture for student achievement. Educational Administration Quarterly, 45(4), 523-555. http://dx.doi.org/10.1177/0013161X09335873

Edmonds, R. (1979, October). Effective Schools for the urban poor. Educational Leadership, 37(22), 15-24.

Firestone, W.A., Mangin, M. M.; Martinez, M. C., \& Polovsky, T. (2005). Leading coherent professional development: A comparison of three districts. Educational Administration Quarterly, 41(3), 413-448. http://dx.doi.org/10.1177/0013161X04269605

Hallinger, P. (2011). Leadership for learning: Lessons from 40 years of empirical research. Journal of Educational Administration, 49(2), $\quad$ 125-142. http://dx.doi.org/10.1108/09578231111116699

Hallinger, P., \& Heck, R.H. (1998). Exploring the principal's contribution to school effectiveness 1980-1995. School Effectiveness and School Improvement, 9(2), 157-191. http://dx.doi.org/10.1080/0924345980090203

Hallinger, P. \& Murphy, J. F. (1987, September). Assessing and developing principal instructional leadership. Educational Leadership, 45(1), 54-61.

Leithwood, K. \& Jantzi, D. (1999). The relative effects of principal and teacher sources of leadership on student engagement with school. Educational Administration Quarterly, 35, 679-706. http://dx.doi.org/10.1177/00131619921968798

Leithwood, K., Patten, S., \& Jantzi, D. (2010). Testing a conception of how school leadership influences student learning. Educational Administration Quarterly, 46, 671-706. DOI: 10.1177/0013161X10377347 
Leithwood, K., \& Riehl, C. (2003, March). What do we already know about successful school leadership. Paper prepared for the AERA Division A Task Force on Developing Research in Educational Leadership.

Leithwood, K. Seashore Louis, K., Anderson, S., \& Wahlstrom, K. (2004). How leadership influences student learning. New York, NY: Wallace Foundation.

Lewthwaite, B. (2004). Are you saying I'm to blame? Exploring the influence of a principal on elementary science delivery. Research in Science Education, 34, 137-152. http://dx.doi.org/10.1023/B:RISE.0000033763.12967.15

McGuigan, L., \& Hoy,W.K. (2006). Principal leadership: Creating a culture of academic optimism to improve achievement for all students. Leadership and Policy in Schools, 5, 203-229. http://dx.doi.org/10.1080/15700760600805816

Marzano, R.J., Waters, T., \& McNulty, B.A. (2005). School leadership that works: From research to results. Alexandria, Va.: Association for Supervision and Curriculum Development.

Mechling, K.R., \& Oliver, D.L. (1983). Handbook II: The principal's role in elementary school science: Project for promoting science among elementary school principals. Washington, D.C.: National Science Teachers Association.

Robinson, V. M. J., Lloyd, C.A., \& Rowe, K.J. (2008). The impact of leadership on student outcomes: An analysis of the differential effects of leadership types. Educational Administration Quarterly, 44, (5), 635-674. http://dx.doi.org/10.1177/0013161X08321509

Ross, J. A. \& Gray, P. (2006). School leadership and student achievement: The mediating effects of teacher beliefs. Canadian Journal of Education, 29(3), 798-822. http://dx.doi.org/10.2307/20054196

Stark-Price, G.A., Munoz, M.A., Winter, P.A., \& Petrosko, J.M. (2006). Recruiting principals to lead low-performing schools: effects on job attractiveness. Journal of Personnel Evaluation in Education, 16(1-2), 69-83.

Supovitz, J, Sirinides, P, \& May, H. (2010). How principals and peers influence teaching and learning. Educational Administration Quarterly, 46(31), Retrieved from http://eaq.sagepub.com/cgi/content/abstract/64/1/31

Texas Education Agency. Texas School Directory 2009-2010. Retrieved from http://mansfield.tea.state.tx.us/TEA.AskTED.TSD/TSDfiles/tsd2010/tagged/texas_school_dir ectory_2009-10_tagged.pdf

Texas Education Agency. (2009, May). 2009 Accountability Manual. Retrieved from http://ritter.tea.state.tx.us/perfreport/account/2009/manual/index.html

Waters, J. T., Marzano, R. J., \& McNulty, B. A. (2003). Balanced leadership: What 30 years of research tells us about the effect of leadership on student achievement. Aurora, CO: Mid-continent Research for Education and Learning. 


\section{Macrothink}

Journal of Studies in Education

ISSN 2162-6952 2012, Vol. 2, No. 2

Wenglinsky, H., \& Silverstein, S.C. (2007). The science training teachers need. Educational Leadership, 64, 24-29.

Witziers, B., Bosker, R.J., \& Kruger, M.L. (2003). Educational leadership and student achievement: the elusive search for an association. Educational Administration Quarterly, 39(3), 398-425. http://dx.doi.org/10.1177/0013161X03253411

Wolcott, H. F. (2009). Writing up qualitative research ( $3^{\text {rd }}$ ed.). Thousand Oaks: Sage. van de Grift, W \& Houtveen, A.A.M. (1999). Educational leadership and pupil achievement in primary education. School Effectiveness and School Improvement, 10 (4), 373389.

Vanderhaar, J. E.; Munoz, M.A.; Rodosky, R.J. (2007). Leadership as accountability for learning: The effects of school poverty, teacher experience, previous achievement, and principal preparation programs on student achievement. Journal of Personnel Evaluation in Education, 19,17-33. http://dx.doi.org/10.1007/s11092-007-9033-8

Ylimaki, R. (2007). Instructional leadership in challenging U.S. schools. International Studies in Educational Administration, 35(3), 11-19.

Zhao, Y. (2009). Catching Up or Leading the Way: American Education in the Age of Globalization. Alexandria VA: Association for Supervision and Curriculum Development.

\section{Copyright Disclaimer}

Copyright reserved by the author(s).

This article is an open-access article distributed under the terms and conditions of the Creative Commons Attribution license (http://creativecommons.org/licenses/by/3.0/). 